ZOOLOGIA 32 (3): 215-224, June 2015

http://dx.doi.org/10.1590/S1984-46702015000300006

\title{
Effect of humic acid on survival, ionoregulation and hematology of the silver catfish, Rhamdia quelen (Siluriformes: Heptapteridae), exposed to different $\mathrm{pHs}$
}

\author{
Silvio T. da Costa ${ }^{1, *}$, Luciane T. Gressler ${ }^{2}$, Fernando J. Sutili², Luíza Loebens ${ }^{1}$, \\ Rafael Lazzari ${ }^{1} \&$ Bernardo Baldisserotto ${ }^{3}$
}

\begin{abstract}
'Departamento de Zootecnia e Ciências Biológicas, Centro de Educação Norte do Rio Grande do Sul, Universidade Federal de Santa Maria. 98300-000 Palmeira das Missões, RS, Brazil.

${ }^{2}$ Programa de Pós-graduação em Farmacologia, Universidade Federal de Santa Maria. 97105-900 Santa Maria, RS, Brazil. ${ }^{3}$ Departamento de Fisiologia e Farmacologia, Universidade Federal de Santa Maria. 97105-900 Santa Maria, RS, Brazil. "Corresponding author. E-mail: silvio.teixeira.da.costa@gmail.com
\end{abstract}

\begin{abstract}
This study evaluates whether humic acid (HA; Aldrich) protects the silver catfish, Rhamdia quelen (Quoy \& Gaimard, 1824), against exposure to acidic $\mathrm{pH}$. Survival, levels of $\mathrm{Na}^{+}, \mathrm{Cl}^{-}$and $\mathrm{K}^{+}$plasma, hematocrit, hemoglobin and erythrocyte morphometry were measured. Fish were exposed to 0, 10, 25 and $50 \mathrm{mg} \mathrm{L}^{1} \mathrm{HA}$ at four pH levels: 3.8, 4.0, 4.2 and 7.0 up to 96 hours. None of the fish exposed to $\mathrm{pH} 3.8$ survived for 96 hours into the experiment, and survival of fish subjected to $\mathrm{pH} 4.0$ decreased when $\mathrm{HA}$ concentration increased. Plasma $\mathrm{Na}^{+}$levels decreased when $\mathrm{pH}$ was acidic, with no influence of $\mathrm{HA}$, while $\mathrm{Cl}^{-}$levels declined at low $\mathrm{pH}$ with increased $\mathrm{HA}$ concentration. The levels of $\mathrm{K}^{+}$at $\mathrm{pH} 4.0$ and 4.2 increased without HA. Hematocrit and hemoglobin augmented under the effect of $\mathrm{HA}$. At pH 4.0 and 4.2 , erythrocytes of fish not exposed to $\mathrm{HA}$ were smaller, an effect that was partially offset by the presence of HA, since the values at $\mathrm{pH} 7.0$ were higher. Although $\mathrm{HA}$ showed some positive effects changes in hematological and plasma $\mathrm{K}^{+a}$ in silver catfish caused by exposure to acidic $\mathrm{pH}$, the overall findings suggest that HA does not protect this species against acidic $\mathrm{pH}$ because it increased mortality and $\mathrm{Cl}^{-}$loss at $\mathrm{pH} 4.0$.
\end{abstract}

KEY WORDS. Blood parameters; humic acid; plasma ion levels; survival.

Dissolved organic matter, an integral part of all ecosystems, results from the decay of plant and animal debris (Thurman 1985). It comprises humic, fulvic, and other organic acids, and is usually quantified as dissolved organic carbon (DOC) (Wood et al. 2011). DOC is known to positively regulate several biotic/abiotic processes (STEINBERG et al. 2007, Wood et al. 2011). In blackwaters, such as those found in forest streams in the Amazon, coastal lagoons in southeastern Brazil, Finnish and Swedish lakes, and Canadian wetlands, DOC may range from 10 to $300 \mathrm{mg} \mathrm{CL}^{-1}$, while its average content in freshwater systems elsewhere is $0.5-4.0 \mathrm{mg} \mathrm{CL}^{-1}$ (Thurman 1985, KüChler et al. 2000, Farjalla et al. 2009). The high levels of DOC account for the acidity of the aquatic environment. In order to thrive in acidic environments, organisms need a certain degree of specialization in their osmoregulatory organs (MATsuo $\&$ VAL 2007).

Low pH (pH 4-5) induces ion loss (Zaions \& BaLdisserotto 2000, Wood et al. 1998, 2002, 2003, GonZaLez et al. 1998, 2002, Bolner \& Baldisserotto 2007, Matsuo \& Val 2007, Duarte et al. 2013) and the interference with gill ionoregulatory mechanisms may also trigger hematological disturbances. Ionic dilution, potentiated by the plasma acidosis prompted by $\mathrm{H}^{+}$entry, affects body fluid distribution. This could promote reduction in plasma volume, swelling of erythrocytes or splenic contraction, resulting in elevation of the hematocrit (Milligan \& Wood 1982). Despite being highly responsible for the acidic nature of blackwaters, there is evidence that DOC protects native fish from the deleterious effects of low $\mathrm{pH}$, reducing ion loss (WooD et al. 1998, 2002, 2003, 2011, Gonzalez et al. 1998, 2002, Matsuo $\&$ VAL 2007). According to some studies, the occurrence of various charged functional groups in the heterogeneous compounds of DOC may change fundamental properties of the gill epithelium, such as the transepithelial potential, thus altering membrane permeability and stimulating ion uptake (Wood et al. 2011). Humic acid also reduces respiratory stress in fish exposed to slightly acidic water, but increases it at more acidic waters (Holland et al. 2014) and decreases lipid peroxidation and modulates the antioxidant system (Riffel et al. 2014). In opposition to the several findings regarding the effects of DOC on ionoregulatory disturbances, respiratory stress and antioxidant system, no evidence has been documented about its influence on the hematology of fish subjected to acidic $\mathrm{pH}$.

2015 | Sociedade Brasileira de Zoologia | www.sbzoologia.org.br | www.scielo.br/zool All content of the journal, except where identified, is licensed under a Creative Commons attribution-type BY-NC. 
This study evaluated whether humic acid (HA), one of the major components of DOC, would offer the silver catfish, Rhamdia quelen (Quoy \& Gaimard, 1824), protection against the physiological disturbances induced by low $\mathrm{pH}$. This species does not naturally inhabit DOC-enriched, acidic waters, so it is not adapted to such conditions. However, different water quality parameters, including $\mathrm{pH}$ and $\mathrm{DOC}$, are present in southern Brazil, where this species is widely cultivated. The outcome of the interaction between such variables should be investigated to improve the rearing conditions of this fish. In laboratory settings, silver catfish juveniles survive for at least 96 hours in the pH 4-9 range (ZaIOnS \& BALDISSERotTo 2000), but exposure to $\mathrm{pH}$ 5.0 is enough to reduce growth in this species (Copatti et al. 2005). Therefore, if humic acid has a protective effect on silver catfish exposed to acidic waters, it could reduce the deleterious effect of low $\mathrm{pH}$ and improve growth in this species.

\section{MATERIAL AND METHODS}

Juvenile silver catfish $(\mathrm{n}=240,73.43 \pm 3.5 \mathrm{~g}, 20.32 \pm$ $1.22 \mathrm{~cm}$, voucher number 19612, Ichthyology Laboratory, Universidade Federal do Rio Grande do Sul) were acquired from a commercial fishery in Santa Maria, southern Brazil, and acclimated in the Laboratório de Fisiologia de Peixes, Universidade Federal de Santa Maria (UFSM) for three weeks. The fish were equally distributed in 8 tanks of $250 \mathrm{~L}$ and kept in dechlorinated tap water under constant aeration $\left(22.14 \pm 1.5^{\circ} \mathrm{C}, 6.05\right.$ $\pm 0.45 \mathrm{mg} \mathrm{L}^{-1}$ dissolved oxygen (DO), $\mathrm{pH} 7.45 \pm 0.13$ and hardness $\left.24.7 \pm 3.9 \mathrm{mg} \mathrm{CaCO}_{3} \mathrm{~L}^{-1}\right)$. The water was totally renewed every second day and siphoning was performed daily two hours after feeding. The fish were fed commercial food for juveniles with $42 \%$ crude protein once a day.

Lyophilized HA (CAT: 0.675-2 Aldrich ${ }^{\circledR} \mathrm{H} 1$ - HA sodium salt) was the source of DOC used in the tests. It was dissolved in water (the same water used in the acclimation tanks) and agitated for 12 hours in a magnetic stirrer to prepare the stock solution. It was not possible to measure the concentration of DOC in the experimental solutions, but estimation of DOC concentration was made based on the fact that the commercial HA corresponded to $\sim 40 \%$ DOC (MCGEER et al. 2002). HA was tested at 0 (control), 10, 25 and $50 \mathrm{mg} \mathrm{L}^{-1} \mathrm{HA}$, the latter corresponding to the nominal DOC concentration of $20 \mathrm{mg} \mathrm{C} \mathrm{L}^{-1}$. These concentrations were chosen because they are within the range observed in the water of the rio Negro Basin (Küchler et al. 2000). At each concentration of $\mathrm{HA}$, four $\mathrm{pH}$ ranges were tested, with the following minimum values: 3.8, 4.0, 4.2 and 7.0 (Table 1 ). The acidic $\mathrm{pH}$ tested in the present study were near the most acidic $\mathrm{pH}(\mathrm{pH}$ 4.0) that allows $100 \%$ survival in silver catfish (ZAions \& Baldisserotto 2000). A pH meter DMPH-2 (Digimed, São Paulo, Brazil) was used to measure the variable four times a day and adjustments to the minimum values within each range were made with sulfuric acid $1 \mathrm{M}$ when necessary. The water in the experimental aquaria was not renewed during exposure time.
Table 1. Ion levels in water at different $\mathrm{pH}$ and humic acid (HA) levels for Rhamdia quelen.

\begin{tabular}{ccccc}
\hline $\mathrm{HA}\left(\mathrm{mg} \mathrm{L}^{-1}\right)$ & $\mathrm{pH}$ & $\mathrm{Na}^{+}\left(\mathrm{mg} \mathrm{L}^{-1}\right)$ & $\mathrm{Cl}^{-}\left(\mathrm{mg} \mathrm{L}^{-1}\right)$ & $\mathrm{K}^{+}\left(\mathrm{mg} \mathrm{L}^{-1}\right)$ \\
\hline 0 & $3.84 \pm 0.5$ & $3.1 \pm 0.3$ & $5.9 \pm 1.0$ & $0.04 \pm 0.01$ \\
& $4.08 \pm 0.4$ & $3.2 \pm 0.7$ & $6.1 \pm 0.9$ & $0.04 \pm 0.01$ \\
& $4.25 \pm 0.4$ & $3.4 \pm 0.8$ & $6.0 \pm 0.9$ & $0.03 \pm 0.02$ \\
& $7.02 \pm 0.3$ & $3.3 \pm 0.4$ & $6.0 \pm 0.8$ & $0.04 \pm 0.02$ \\
\hline 10 & $3.87 \pm 0.5$ & $3.7 \pm 0.3$ & $5.6 \pm 1.3$ & $0.03 \pm 0.01$ \\
& $4.09 \pm 0.6$ & $3.7 \pm 0.3$ & $5.7 \pm 1.4$ & $0.03 \pm 0.01$ \\
& $4.22 \pm 0.3$ & $3.6 \pm 0.2$ & $6.8 \pm 1.6$ & $0.04 \pm 0.02$ \\
& $7.03 \pm 0.4$ & $4.3 \pm 0.4$ & $6.0 \pm 0.7$ & $0.05 \pm 0.02$ \\
\hline 25 & $3.83 \pm 0.4$ & $3.8 \pm 0.6$ & $6.1 \pm 0.6$ & $0.04 \pm 0.02$ \\
& $4.05 \pm 0.5$ & $4.3 \pm 1.1$ & $5.8 \pm 0.8$ & $0.04 \pm 0.01$ \\
& $4.27 \pm 0.6$ & $3.9 \pm 0.5$ & $6.3 \pm 1.0$ & $0.05 \pm 0.02$ \\
& $7.05 \pm 0.5$ & $3.9 \pm 0.2$ & $6.2 \pm 1.2$ & $0.03 \pm 0.02$ \\
\hline 50 & $3.81 \pm 0.2$ & $4.9 \pm 0.4$ & $6.1 \pm 1.6$ & $0.04 \pm 0.02$ \\
& $4.02 \pm 0.2$ & $4.7 \pm 0.5$ & $6.4 \pm 0.8$ & $0.03 \pm 0.01$ \\
& $4.21 \pm 0.1$ & $4.8 \pm 0.9$ & $6.5 \pm 1.3$ & $0.05 \pm 0.02$ \\
& $7.02 \pm 0.3$ & $5.5 \pm 1.3$ & $6.0 \pm 1.6$ & $0.05 \pm 0.02$ \\
\hline
\end{tabular}

Mean values $\pm S E$ ( $n=4 /$ group for ions). There was no significant difference between treatments.

Juveniles were fasted for 24 hours prior to being transfered to $40 \mathrm{~L}$ aquaria (16 treatments, three replicates of each treatment, five fish per replicate) for the 96-h experiment. Survival was observed four times a day and the dead fish were removed from the aquaria. Fish that survived up to the end of the experimental period were anesthetized with eugenol $50 \mathrm{mg} \mathrm{L}^{-1}$ (CunHA et al. 2010) and their blood was rapidly collected from the caudal vein with heparinized syringes. After sampling, fish were killed by sectioning the spinal cord. All procedures were conducted with the approval of the Ethics Committee on Animal Experimentation of the UFSM (registration \#128/2010).

DO levels and temperature were measured daily with Orion 810 oxygen meter (Thermo Electron Corporation, Waltham, Al, USA). Water samples were collected every second day to verify total ammonia (VERDOUw et al. 1978), un-ionized ammonia, hardness (EATON et al. 2005), nitrite (Boyd \& TUCKER 1992), Cl- (ZALL et al. 1956), and $\mathrm{Na}^{+}$and $\mathrm{K}^{+}$levels, which were measured in a flame photometer (Micronal B262, São Paulo, Brazil). Details on the composition of the water are provided in Tables 1 and 2 . There were no significant differences in water quality parameters between treatments.

To obtain the hematocrit, microcapillary tubes were filled with blood immediately after euthanasia and centrifuged at $10000 \mathrm{Xg}$ for 5 minutes, and the results were obtained using a hematocrit card reader. The concentration of hemoglobin was determined by the cyanmethemoglobin method using a spectrophotometer (Brown 1976). For the morphometric analyses, blood smears were prepared immediately from the whole blood, 
air-dried, fixed in methanol and stained with May-Grünwald (TAVARES-Dias et al. 2004). The surface area and the major and minor axes of the erythrocyte as well as of its nucleus were determined (Dorafshan et al. 2008). Briefly, ten high-power fields were randomly selected on each blood smear, and morphometry of ten erythrocytes were determined in each of these fields. All analyses were performed using the Zeiss Axio Vision System with Remote Capture 4.7 Rel DC - Cannon Power shot G9.

Blood samples were spun at $3000 \mathrm{Xg}$ for 10 minutes and plasma was stored at $-25^{\circ} \mathrm{C}$ until analyses of $\mathrm{Na}^{+}, \mathrm{Cl}^{-}$and $\mathrm{K}^{+}$. The ion levels in the plasma were determined as previously described for the water ion levels.

Homogeneity of variances was assessed via Levene test and the comparison between treatments was carried out by two-way ANOVA and Tukey test. The Kruskal-Wallis test, followed by multiple comparisons of mean ranks, was used for analyses of plasma ion levels (Statistica 7.0 software). Minimum level of significance was $95 \%(\mathrm{p}<0.05)$. Data are presented as mean \pm standard error (SE).

\section{RESULTS}

\section{Survival}

None of the fish exposed to $\mathrm{pH} 3.8$ survived the 96 hours of experiment. At $\mathrm{pH} 4.0$ there was a progressive decrease in survival (100, 86, 60 and 40\%) with increased HA level $(0,10,25$ and $50 \mathrm{mg} \mathrm{L}^{-1} \mathrm{HA}$, respectively). The survival rates at $\mathrm{pH} 4.2$ (93.33\%) and $7.0(100 \%)$ were not affected by HA concentration. Survival at $\mathrm{pH} 4.0$ was lower than at $\mathrm{pH} 4.2$ and 7.0 at all treatments with the presence of HA (i.e. 10, 25 and $50 \mathrm{mg} \mathrm{L}^{-1}$ of HA) (Fig. 1).

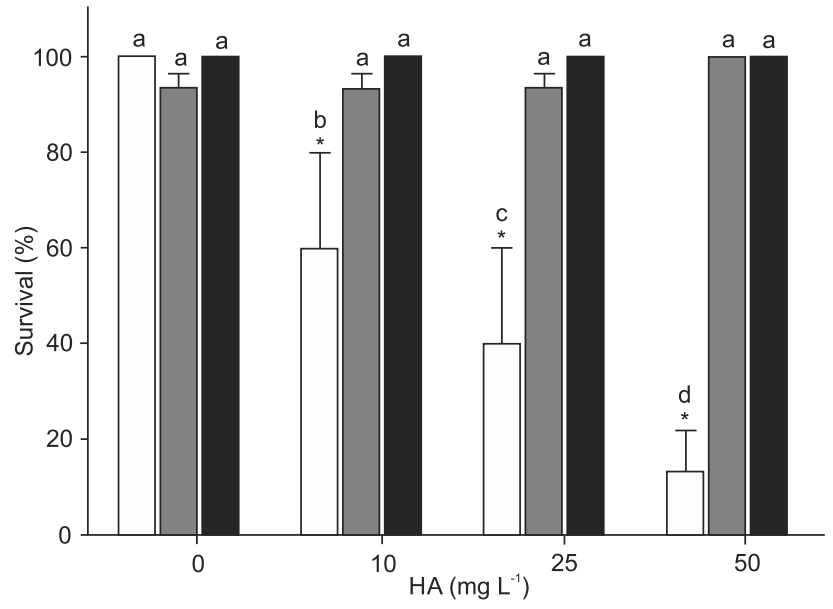

Figure 1. Effect of humic acid $(\mathrm{HA})$ and $\mathrm{pH}$ on survival of silver catfish (Rhamdia quelen). Different letters indicate significant difference between $\mathrm{HA}$ concentrations at the same $\mathrm{pH}$. * indicate significant difference from $\mathrm{pH} 7.0$ at the same HA concentration $(\mathrm{p}<0.05)$. Mean values $\pm \mathrm{SE}(\mathrm{n}=6-15 /$ group $) .(\square) \mathrm{pH} 4.0$, ( $\square)$ $\mathrm{pH} 4.2$, (ם) $\mathrm{pH} 7.0$.

\section{Hematocrit and hemoglobin}

Overall, HA triggered an increase in the percentages of hematocrit and hemoglobin. The presence of HA promoted an increase in the percentage hematocrit at $\mathrm{pH} 4.0$ and 4.2. Upon exposure to $\mathrm{pH} 7.0$, fish experienced a gradual increase in hematocrit from 0 to $25 \mathrm{mg} \mathrm{L}^{-1} \mathrm{HA}$. Hematocrit declined with the

Table 2. Water quality parameters at different $\mathrm{pH}$ and humic acid (HA) levels for Rhamdia quelen.

\begin{tabular}{|c|c|c|c|c|c|c|c|}
\hline $\begin{array}{c}\mathrm{HA} \\
\left(\mathrm{mg} \mathrm{L}^{-1}\right) \\
\end{array}$ & $\mathrm{pH}$ & $\begin{array}{c}\text { Total ammonia } \\
\left(\mathrm{mg} \mathrm{L}^{-1}\right)\end{array}$ & $\begin{array}{c}\text { Un-ionized ammonia } \\
\left(\mathrm{mg} \mathrm{L}^{-1}\right)\end{array}$ & $\begin{array}{l}\text { Nitrite } \\
\left(\mathrm{mg} \mathrm{L}^{-1}\right)\end{array}$ & $\begin{array}{c}\text { Hardness } \\
\left(\mathrm{mg} \mathrm{CaCO}_{3} \mathrm{~L}^{-1}\right)\end{array}$ & $\begin{array}{c}\text { Temperature } \\
\left({ }^{\circ} \mathrm{C}\right)\end{array}$ & $\begin{array}{c}\text { Dissolved oxygen } \\
\left(\mathrm{mg} \mathrm{L}^{-1}\right)\end{array}$ \\
\hline \multirow[t]{4}{*}{0} & 3.8 & $0.85 \pm 0.0015$ & $0.0342 \pm 0.0009$ & $0.3181 \pm 0.012$ & $25.8 \pm 4.2$ & $21.4 \pm 2.1$ & $6.25 \pm 0.61$ \\
\hline & 4.0 & $0.44 \pm 0.0010$ & $0.0251 \pm 0.0003$ & $0.3492 \pm 0.025$ & $25.7 \pm 4.1$ & $21.2 \pm 2.2$ & $6.21 \pm 0.64$ \\
\hline & 4.2 & $0.16 \pm 0.0004$ & $0.0270 \pm 0.0004$ & $0.3758 \pm 0.032$ & $27.3 \pm 6.1$ & $21.2 \pm 2.6$ & $6.10 \pm 0.45$ \\
\hline & 7.0 & $0.32 \pm 0.0010$ & $0.0279 \pm 0.0005$ & $0.3625 \pm 0.041$ & $26.1 \pm 5.8$ & $21.3 \pm 2.6$ & $6.08 \pm 0.54$ \\
\hline \multirow[t]{4}{*}{10} & 3.8 & $0.76 \pm 0.01$ & $0.0027 \pm 0.0003$ & $0.4011 \pm 0.013$ & $26.8 \pm 5.6$ & $20.1 \pm 2.0$ & $6.12 \pm 0.61$ \\
\hline & 4.0 & $0.92 \pm 0.021$ & $0.0028 \pm 0.0002$ & $0.3442 \pm 0.022$ & $25.1 \pm 4.8$ & $20.2 \pm 2.1$ & $6.14 \pm 0.48$ \\
\hline & 4.2 & $0.83 \pm 0.014$ & $0.0027 \pm 0.0004$ & $0.2034 \pm 0.024$ & $27.6 \pm 5.1$ & $20 \pm 2.1$ & $6.18 \pm 0.45$ \\
\hline & 7.0 & $1.09 \pm 0.032$ & $0.1820 \pm 0.0019$ & $0.3285 \pm 0.045$ & $26.3 \pm 4.9$ & $20.4 \pm 2.0$ & $6.17 \pm 0.48$ \\
\hline \multirow[t]{3}{*}{25} & 3.8 & $0.74 \pm 0.012$ & $0.015 \pm 0.0003$ & $0.4101 \pm 0.023$ & $26.1 \pm 5.1$ & $21.4 \pm 1.9$ & $6.26 \pm 0.62$ \\
\hline & 4.0 & $0.87 \pm 0.017$ & $0.027 \pm 0.0003$ & $0.4119 \pm 0.025$ & $25.9 \pm 5.2$ & $22 \pm 1.3$ & $6.11 \pm 0.53$ \\
\hline & 4.2 & $1.22 \pm 0.024^{*}$ & $0.215 \pm 0.0150$ & $0.3289 \pm 0.034$ & $26.4 \pm 5.4$ & $21.5 \pm 2.4$ & $6.15 \pm 0.60$ \\
\hline \multirow[t]{4}{*}{50} & 3.8 & $0.64 \pm 0.011$ & $0.019 \pm 0.0006$ & $0.4516 \pm 0.024$ & $26.4 \pm 5.0$ & $21.1 \pm 2.3$ & $6.21 \pm 0.65$ \\
\hline & 4.0 & $0.66 \pm 0.012$ & $0.019 \pm 0.0005$ & $0.3442 \pm 0.039$ & $27.1 \pm 4.9$ & $21.1 \pm 2.1$ & $6.24 \pm 0.39$ \\
\hline & 4.2 & $0.75 \pm 0.015$ & $0.021 \pm 0.0007$ & $0.2034 \pm 0.054$ & $26.1 \pm 5.1$ & $21.0 \pm 2.0$ & $6.18 \pm 0.53$ \\
\hline & 7.0 & $0.81 \pm 0.014$ & $0.022 \pm 0.0009$ & $0.3285 \pm 0.061$ & $26.2 \pm 5.2$ & $20.9 \pm 2.0$ & $6.19 \pm 0.55$ \\
\hline
\end{tabular}

*Significantly different from $\mathrm{pH} 4.2$ and HA $0 \mathrm{mg} \mathrm{L}^{-1}(\mathrm{p}<0.05)$. Mean values $\pm \mathrm{SE}(\mathrm{n}=4 / \mathrm{group})$. 
increase in $\mathrm{pH}$ at $0 \mathrm{mg} \mathrm{L}^{-1} \mathrm{HA}$. Exposure to $10 \mathrm{mg} \mathrm{L}^{-1} \mathrm{HA}$ induced significantly higher hematocrit percentage at $\mathrm{pH} 4.0$ and 4.2, while at $25 \mathrm{mg} \mathrm{L}^{-1} \mathrm{HA}$ the $\mathrm{pH}$ had negligible influence on hematocrit. Treatment with $50 \mathrm{mg} \mathrm{L}^{-1} \mathrm{HA}$ caused a significantly reduction in hematocrit concentration at pH 7.0 (Fig. 2).

There was no difference in the percentage of hemoglobin between HA treatments at $\mathrm{pH}$ 4.2. Exposure to $\mathrm{pH} 4.0$ induced a higher hemoglobin level at $25 \mathrm{mg} \mathrm{L}^{-1} \mathrm{HA}$ than at $0 \mathrm{mg} \mathrm{L}^{-1} \mathrm{HA}$. When fish were exposed to $\mathrm{pH} 7.0$ the hemoglobin was lower at 50 than at $10 \mathrm{mg} \mathrm{L}^{-1} \mathrm{HA}$, and at $0 \mathrm{mg} \mathrm{L}^{-1} \mathrm{HA}$ was also lower than at $25 \mathrm{mg} \mathrm{L}^{-1} \mathrm{HA}$. In the absence of HA the levels of hemoglobin decreased as the $\mathrm{pH}$ increased. Exposure to $10 \mathrm{mg} \mathrm{L}^{-1} \mathrm{HA}$ did not induce differences in hemoglobin values between the different $\mathrm{pH}$. Hemoglobin levels at $25 \mathrm{mg} \mathrm{L}^{-1} \mathrm{HA}$ were higher at $\mathrm{pH} 4.0$ than at $\mathrm{pH} 4.2$ and 7.0. On exposure to $50 \mathrm{mg} \mathrm{L}^{-1} \mathrm{HA}$ the hemoglobin levels were higher at $\mathrm{pH} 4.0$ and 4.2 than at $\mathrm{pH} 7.0$ (Fig. 3).
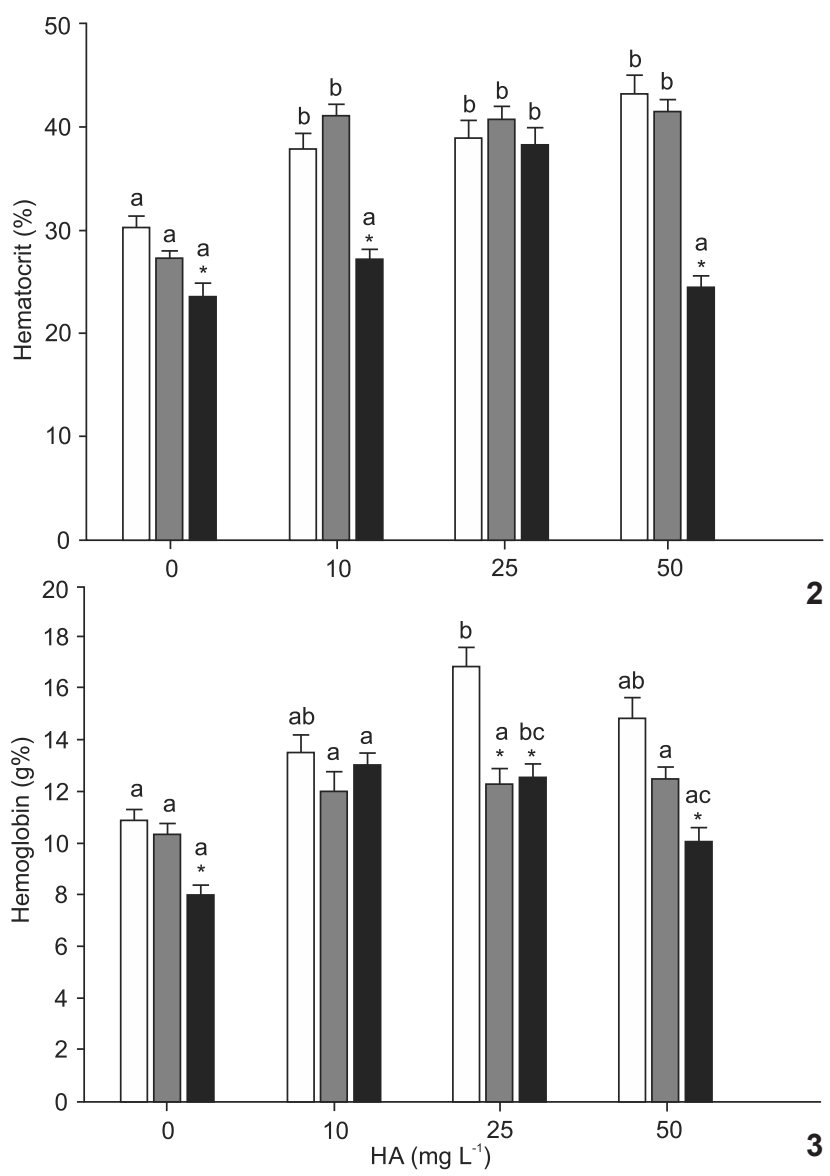

Figures 2-3. Effect of humic acid (HA) and $\mathrm{pH}$ on hematocrit (2) and hemoglobin (3) of silver catfish (Rhamdia quelen). Different letters indicate significant difference between $\mathrm{HA}$ concentrations at the same $\mathrm{pH} .{ }^{*}$ indicate significant difference from $\mathrm{pH} 7.0$ at the same HA concentration $(p<0.05)$. Mean values \pm SE $(n=6-$

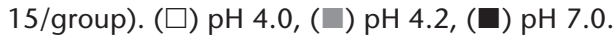

\section{Erythrocyte morphometry}

Fish subjected to $\mathrm{pH} 4.0$ showed greater cell area and cell minor and major axes in the presence of HA than in the absence of it. At pH 4.2, cell area was larger at 10 and $50 \mathrm{mg} \mathrm{L}^{-1}$ $\mathrm{HA}$ than at $25 \mathrm{mg} \mathrm{L}^{-1} \mathrm{HA}$, and it decreased further when HA was not present. At the same $\mathrm{pH}$ (4.2), cell minor axis was bigger at 50 than at 0 and $25 \mathrm{mg} \mathrm{L}^{-1} \mathrm{HA}$; it was also bigger at $10 \mathrm{mg}$ $\mathrm{L}^{-1} \mathrm{HA}$ compared to $0 \mathrm{mg} \mathrm{L}^{-1} \mathrm{HA}$. At $0 \mathrm{mg} \mathrm{L}^{-1} \mathrm{HA}$, cell area and its minor and major axes were bigger at $\mathrm{pH} 7.0$ than at $\mathrm{pH}$ 4.0. The group exposed to $25 \mathrm{mg} \mathrm{L}^{-1} \mathrm{HA}$ presented greater cell area at $\mathrm{pH} 7.0$ than at all the acidic $\mathrm{pH}$ and greater cell minor axis at $\mathrm{pH} 7.0$ than at $\mathrm{pH} 4.2$. Fish treated with $50 \mathrm{mg} \mathrm{L}^{-1} \mathrm{HA}$ had bigger cell minor axis at $\mathrm{pH} 4.2$ than at $\mathrm{pH} 4.0$, and bigger cell major axis at pH 7.0 comparing with $\mathrm{pH} 4.0$ (Table 3).

\section{Plasma $\mathrm{Na}^{+}, \mathrm{Cl}^{-}$and $\mathrm{K}^{+}$}

In $\mathrm{Na}^{+}$levels, no significant differences were observed in fish exposed to the different HA treatments at $\mathrm{pH} 4.0$ and 7.0, but at $\mathrm{pH} 4.2$, exposure to $25 \mathrm{mg} \mathrm{L}^{-1} \mathrm{HA}$ increased $\mathrm{Na}^{+}$levels compared to the group non exposed to HA. Silver catfish exposed to $\mathrm{pH} 4.0$ and 4.2 without HA presented significantly lower $\mathrm{Na}^{+}$levels than those at $\mathrm{pH} 7.0$ without $\mathrm{HA}$, but at $10 \mathrm{mg} \mathrm{L}^{-1} \mathrm{HA}$ plasma $\mathrm{Na}^{+}$in fish exposed to $\mathrm{pH} 4.2$ were not significantly different from $\mathrm{pH}$ 7.0. Fish at $25 \mathrm{mg} \mathrm{L}^{-1} \mathrm{HA}$ and $\mathrm{pH} 4.2$ presented significantly higher $\mathrm{Na}^{+}$levels than at $\mathrm{pH} 7.0$ (Fig. 4).

The levels of $\mathrm{Cl}^{-}$at $\mathrm{pH} 4.0$ were significantly greater in fish exposed to $10 \mathrm{mg} \mathrm{L}^{-1} \mathrm{HA}$, while at $\mathrm{pH} 4.2$ and 7.0 $\mathrm{HA}$ did not affect significantly plasma $\mathrm{Cl}^{-}$. Fish subjected to $10 \mathrm{mg} \mathrm{L}^{-1}$ had higher $\mathrm{Cl}^{-}$levels at $\mathrm{pH} 7.0$ and 4.0 than at $\mathrm{pH} 4.2$. Plasma $\mathrm{Cl}^{-}$levels were significantly lower at $25 \mathrm{mg} \mathrm{L}^{-1} \mathrm{HA}$ and $\mathrm{pH} 4.0$ and at $50 \mathrm{mg} \mathrm{L}^{-1}$ and $\mathrm{pH} 4.0$ and 4.2 than at $\mathrm{pH} 7.0$ and the same HA levels (Fig. 5).

$\mathrm{K}^{+}$levels were not affect by HA treatments at $\mathrm{pH}$ 7.0. However, significantly higher $\mathrm{K}^{+}$levels were observed at $0 \mathrm{mg} \mathrm{L}^{-1} \mathrm{HA}$ than at $10 \mathrm{mg} \mathrm{L}^{-1} \mathrm{HA}$ and $\mathrm{pH} 4.0$, and at 25 and $50 \mathrm{mg} \mathrm{L}^{-1} \mathrm{HA}$ and $\mathrm{pH}$ 4.2. The levels of $\mathrm{K}^{+}$were significantly higher at $\mathrm{pH} 4.0$ and 4.2 than at pH 7.0 in fish kept in water without HA (Fig. 6).

\section{DISCUSSION}

All water parameters analyzed were within the limits that permit normal growth and survival of silver catfish (e.g. nitrite and un-ionized ammonia levels below $1.2 \mathrm{mg} \mathrm{L}^{-1}$ and 0.1 $\mathrm{mg} \mathrm{L}^{-1}$ respectively) (Lima et al. 2011, Miron et al. 2011).

According to Zaions \& BaLdisserotTo (2000), even though silver catfish presents a marked loss of $\mathrm{Na}^{+}$at $\mathrm{pH} 4.0$, this is the acidic $\mathrm{pH}$ threshold for the species survival, at least for $96 \mathrm{~h}$. In the present assessment this assertion was confirmed by the $0 \%$ survival of fish exposed to $\mathrm{pH} 3.8$ regardless the HA concentrations. As stated by Wood \& McDonald (1982), nonacidophilic species suffocate at $\mathrm{pH}$ levels below 4.0 due to gill structural damage, edema and mucification. Moreover, fish mortality in acid waters is largely associated with a failure to 

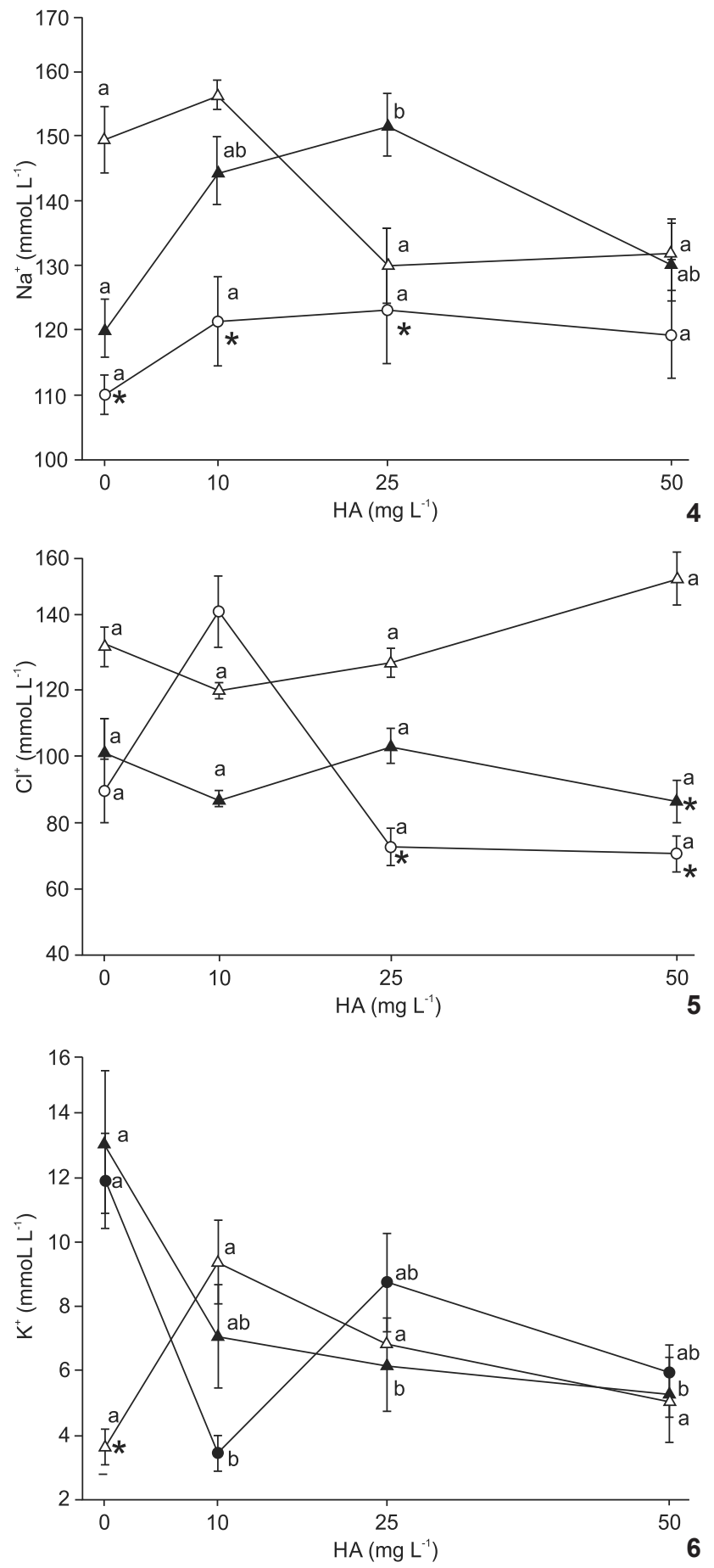

Figures 4-6. Effect of humic acid ( $\mathrm{HA})$ and $\mathrm{pH}$ on plasma $\mathrm{Na}^{+}(4)$, $\mathrm{Cl}^{-}(5)$ and $\mathrm{K}^{+}(6)$ of silver catfish (Rhamdia quelen). Different letters indicate significant difference between HA concentrations at the same $\mathrm{pH} .{ }^{*}$ indicate significant difference from $\mathrm{pH} 7.0$ at the same HA concentration $(p<0.05)$. Mean values \pm SE $(n=6-15 /$ group). ( $\bigcirc) \mathrm{pH} 4.0,(\mathbf{\Delta}) \mathrm{pH} 4.2,(\triangle) \mathrm{pH} 7.0$. ionoregulate, especially due to stimulation of $\mathrm{Na}^{+}$efflux (Milligan \& Wood 1982). A study on shiners Notropis cornutus (Mitchill, 1817), rainbow trout Oncorhynchus mykiss (Walbaum, 1792) and perch Perca flavescens (Mitchill, 1814) clearly proved that principle by showing that a great amount of $\mathrm{Na}^{+}$and $\mathrm{Cl}^{-}$ (50-60\%) had been lost at death after exposure to $\mathrm{pH} 4.0$ (FREDA $\&$ McDonald 1988). Similarly, Holland et al. (2014) reported increased morbidity of the eastern rainbow fish Melanotaenia splendida splendida (Peters, 1866) as the $\mathrm{pH}$ dropped to 3.5-4.0 in the presence of commercial HA, despite having observed a protective effect of the substance at higher acidic levels. The authors suggested that HA may have enhanced the toxicity of low $\mathrm{pH}$ by increasing ion loss in the fish.

At $\mathrm{pH}$ 4.0, HA displayed a deleterious effect on the physiology of silver catfish; increased concentration of HA was associated with a decline in fish survival. Costa et al. (pers. comm.) observed that the presence of HA induces proliferation of chloride cells in the lamellae of the gill of silver catfish. Gas transfer in pavement cells might be impaired when chloride cells inundate the lamellae, since thickening of the lamellar epithelium increases blood-to-water diffusion distance (GRECO et al. 1996). Bindon et al. (1994) previously reported a reduction in the lamellar epithelium as a consequence of chloride cell proliferation. Thus, the silver catfish may have been unable to cope with the combination of limited gas exchange, due to increased concentrations of HA, and ionic loss, the result of extreme $\mathrm{pH}$. At higher $\mathrm{pH}$ levels, however, the detrimental effect of HA was not observed, most likely because at low $\mathrm{pH}$ the excess positive charge titrates away the negatively charged groups associated with the extracellular surface of epithelial membranes (CAmpBell et al. 1997). This reduces the electrochemical repulsion between the membrane and the negatively charged HA, allowing the two parameters to associate and induce an effect. However, as $\mathrm{pH}$ increases the decrease in positive charge means that the HA is now less electrochemically favored to associate with the membrane and thus the effect is diminished.

As stated by ARIDE et al. (2007), acid stress triggers various changes in hematological parameters of freshwater fish. When it takes place, the generated osmotic and ionic gradient favors the entry of water into intracellular space and electrolyte flux in the opposite direction. With that, blood volume decreases, erythrocyte physiology changes, hematocrit, hemoglobin and plasma protein levels rise, and ion loss through the gills is further enhanced (Wood et al. 1998, Aride et al. 2007). Water acidification is also associated with blood acidosis. It affects the oxygenation capacity of the hemoglobin and $\mathrm{PO}_{2}$ is thus reduced, which in turn triggers an increase in hematocrit and hemoglobin in order to restore proper homeostatic control (McDonald \& Wood 1981, Dheer et al. 1987). Milligan \& Wood (1982) found increases in both hematocrit and hemoglobin in rainbow trout during acid exposure. The authors stated that hematocrit elevation probably resulted from a re- 
Table 3. Effect of humic acid and $\mathrm{pH}$ on erythrocyte morphology of Rhamdia quelen.

\begin{tabular}{|c|c|c|c|c|}
\hline & \multicolumn{4}{|c|}{ Humic acid (mg L-1) } \\
\hline & 0 & 10 & 25 & 50 \\
\hline \multicolumn{5}{|l|}{$\mathrm{pH} 4.0$} \\
\hline Cell area $\left(\mu m^{2}\right)$ & $98.73 \pm 15.9^{\mathrm{a}^{*}}$ & $146.82 \pm 20.3^{b}$ & $135.92 \pm 13.3^{\mathrm{b}^{*}}$ & $136.30 \pm 6.48^{\mathrm{b}^{*}}$ \\
\hline Cell minor axis $(\mu \mathrm{m})$ & $9.55 \pm 1.00^{\mathrm{a}^{*}}$ & $11.75 \pm 0.75^{b}$ & $11.26 \pm 0.70^{\mathrm{b}}$ & $11.32 \pm 0.31^{\mathrm{b}}$ \\
\hline Cell major axis $(\mu \mathrm{m})$ & $13.32 \pm 0.92^{\mathrm{a}^{*}}$ & $16.13 \pm 1.11^{\mathrm{b}}$ & $15.67 \pm 0.73^{b}$ & $15.60 \pm 0.51^{\mathrm{b}^{*}}$ \\
\hline Nucleus minor axis $(\mu \mathrm{m})$ & $4.16 \pm 0.47^{a}$ & $4.42 \pm 0.29^{a}$ & $4.58 \pm 0.19^{a}$ & $5.77 \pm 2.81^{\mathrm{a}}$ \\
\hline Nucleus major axis $(\mu \mathrm{m})$ & $5.79 \pm 0.51^{\mathrm{a}}$ & $6.12 \pm 0.80^{\mathrm{a}}$ & $6.21 \pm 0.37^{a}$ & $7.70 \pm 3.66^{\mathrm{a}}$ \\
\hline \multicolumn{5}{|l|}{$\mathrm{pH} 4.2$} \\
\hline Cell area $\left(\mu \mathrm{m}^{2}\right)$ & $122.70 \pm 6.15^{a}$ & $139.88 \pm 7.38^{\mathrm{b}}$ & $132.82 \pm 4.57^{c^{*}}$ & $144.73 \pm 6.47^{b}$ \\
\hline Cell minor axis $(\mu \mathrm{m})$ & $10.52 \pm 0.36^{\mathrm{a}}$ & $11.45 \pm 0.27^{b c}$ & $11.09 \pm 0.53^{\mathrm{ac}^{*}}$ & $11.94 \pm 0.39^{b}$ \\
\hline Nucleus area $\left(\mu \mathrm{m}^{2}\right)$ & $20.07 \pm 1.60^{a}$ & $20.23 \pm 2.61^{a}$ & $20.87 \pm 1.31^{\mathrm{a}}$ & $18.45 \pm 1.47^{a}$ \\
\hline Nucleus minor axis $(\mu \mathrm{m})$ & $4.34 \pm 0.18^{a}$ & $4.43 \pm 0.32^{\mathrm{a}}$ & $4.48 \pm 0.15^{a}$ & $4.27 \pm 0.26^{a}$ \\
\hline Nucleus major axis $(\mu \mathrm{m})$ & $6.03 \pm 0.28^{\mathrm{a}}$ & $5.99 \pm 0.33^{\mathrm{a}}$ & $6.30 \pm 0.39^{a}$ & $5.73 \pm 0.27^{\mathrm{a}}$ \\
\hline \multicolumn{5}{|l|}{$\mathrm{pH} 7.0$} \\
\hline Cell area $\left(\mu \mathrm{m}^{2}\right)$ & $135.11 \pm 19.63^{a}$ & $151.22 \pm 20.83^{a}$ & $155.43 \pm 12.71^{a}$ & $153.34 \pm 14.78^{a}$ \\
\hline Cell minor axis $(\mu \mathrm{m})$ & $11.21 \pm 0.95^{a}$ & $11.88 \pm 0.79$ & $12.21 \pm 0.57^{a}$ & $11.81 \pm 0.23^{\mathrm{a}}$ \\
\hline Cell major axis $(\mu \mathrm{m})$ & $15.52 \pm 1.08^{a}$ & $16.45 \pm 1.19^{a}$ & $16.51 \pm 0.66^{a}$ & $16.85 \pm 1.30^{\mathrm{a}}$ \\
\hline Nucleus area $\left(\mu \mathrm{m}^{2}\right)$ & $20.63 \pm 3.53^{a}$ & $23.73 \pm 3.63^{a}$ & $22.43 \pm 2.40^{a}$ & $22.02 \pm 1.78^{\mathrm{a}}$ \\
\hline Nucleus minor axis $(\mu \mathrm{m})$ & $4.48 \pm 0.35^{a}$ & $4.67 \pm 0.38^{a}$ & $4.67 \pm 0.29^{a}$ & $4.55 \pm 0.09^{a}$ \\
\hline Nucleus major axis $(\mu \mathrm{m})$ & $6.04 \pm 0.55^{\mathrm{a}}$ & $6.66 \pm 0.51^{\mathrm{a}}$ & $6.31 \pm 0.32^{\mathrm{ab}}$ & $6.38 \pm 0.40^{\mathrm{a}}$ \\
\hline
\end{tabular}

Different letters indicate significant difference between $\mathrm{HA}$ concentrations at the same $\mathrm{pH} .{ }^{*}$ Indicate significant difference from $\mathrm{pH} 7.0$ at the same $\mathrm{HA}$ concentration $(p<0.05)$. Mean values \pm SE $(n=8-15 /$ group $)$.

duction in plasma volume, erythrocyte swelling and release of erythrocytes from the spleen due to increased circulating catecholamines.

In this investigation, both hematocrit and hemoglobin were highly affected by the experimental variables, considering the basal range previously reported for silver catfish, 17.0034.00 and 4.95-9.09 respectively (TaVares-Dias et al. 2002). Some of the groups exposed to higher $\mathrm{pH}$ levels increased hematocrit and hemoglobin values in the presence of HA, which may be a result of the before-mentioned limited gas exchange induced by HA. Inefficient gill ventilation triggers mechanisms such as splenic contraction in an attempted to absorb more oxygen, therefore elevating hematocrit and hemoglobin (SAMPAIO et al. 2008). Riffel et al. (2014) have similarly reported that the addition of HA to the water, though at low concentrations, induced hematocrit and hemoglobin rises in silver catfish at neutral $\mathrm{pH}$.

Somewhat different results were found at $\mathrm{pH} 7.0$ for the hematocrit in the group subjected to $10 \mathrm{mg} \mathrm{L}^{-1} \mathrm{HA}$ and for both the hematocrit and hemoglobin in the group exposed to $50 \mathrm{mg} \mathrm{L}^{-1} \mathrm{HA}$. It seems that the fish in those groups, especially in the latter one, were able to compensate for the decreased ventilatory drive caused by $\mathrm{HA}$ at the neutral $\mathrm{pH}$, which was not observed at $25 \mathrm{mg} \mathrm{L}^{-1} \mathrm{HA}$.

Exposure of tambaqui to an extreme $\mathrm{pH}$ of 3.0 had no influence on blood oxygenation or hemoglobin concentration, demonstrating that this fish, which migrates from circumneutral to acidic waters in its natural habitat, does not encounter challenges in oxygen delivery at such pH level (Wood et al. 1998). Likewise, Aride et al. (2007) observed similar hemoglobin levels between tambaqui subjected to either circumneutral or acid $\mathrm{pH}$, though there was elevation in hematocrit during acid exposure.

As already mentioned, Milligan \& Wood (1982) found that acid exposure triggered disturbances in hematological homeostasis and fluid volume distribution in rainbow trout. Elevation in erythrocyte volume in that species was most likely a result of fluid redistribution from extra- to intracellular compartments due to the ionic dilution of the plasma. In contrast, ARIDE et al. (2007) observed no changes in erythrocyte volume in tambaqui subjected to acid exposure. In the present study it was demonstrated that: a) regardless the HA concentration, the size of the erythrocytes and their nuclei remained stable throughout the groups at $\mathrm{pH} 7.0 ; \mathrm{b}$ ) at $\mathrm{pH} 4.0$ and 4.2 , 
the significant differences indicate smaller values in the $a b$ sence of HA; and c) within a given concentration of HA, most differences pointed to higher values at $\mathrm{pH} 7.0$ than at acidic $\mathrm{pH}$. The overall response suggests that, unlike the studies cited above, low $\mathrm{pH}$ caused a shrinking effect on the erythrocytes of silver catfish. The presence of HA did not fully counteract such outcome, since the differences were significant comparing to $\mathrm{pH}$ 7.0 This effect could be due to output of water and hydromineral disturbance, which typically arise from stress in fish (WendelaAr Bonga 1997).

Plasma levels of $\mathrm{Na}^{+}$of silver catfish at $\mathrm{pH} 4.0$ and 4.2 were lower than those observed at $\mathrm{pH}$ 7.0. The disruptive process in this extreme aquatic environment primarily involves active inhibition of ion uptake and increased ion loss in the gills (Milligan \& Wood 1982). Freda \& McDonald (1988) observed the complete inhibition of $\mathrm{Na}^{+}$influx in shiners and trout exposed to $\mathrm{pH} 4.0$, in addition to an increase in the ion outward flux. LIN \& RANDALL (1993) claimed that inhibition of $\mathrm{Na}^{+}$uptake at low $\mathrm{pH}$ results from the reduced activity of an apical electrogenic $\mathrm{H}^{+}$ATPase that energizes an apical $\mathrm{Na}^{+}$channel in chloride cells, an effect attributed to the $\mathrm{H}^{+}$gradient. Stimulation of $\mathrm{Na}^{+}$efflux, which is the primary determinant of low $\mathrm{pH}$ tolerance, is usually a consequence of the $\mathrm{H}^{+}$-induced $\mathrm{Ca}^{2+}$ leaching from the paracellular channels in the gills (GonZALEZ et al. 1997).

McDonald \& Wood (1981) and Wood et al. (1998) stated that disturbance of ionoregulation by high external $\mathrm{H}^{+}$is likely to occur in nonacidophilic species when they are subjected to a sudden acid stress. On the other hand, fish that inhabit naturally acidified, diluted waters, such as those found in the Amazon basin or along the eastern coast of the United States, show a greater tolerance to high concentration of water $\mathrm{H}^{+}$and have a lower $\mathrm{pH}$ threshold at which marked ion losses occur (Gonzalez \& Dunson 1989, Gonzalez et al. 1998, Wood et al. 1998, Matsuo \& Val 2007). In some species the adaptation to thrive in these waters involves increased branchial affinity for $\mathrm{Ca}^{2+}$ at the paracellular junction, thus counteracting low $\mathrm{pH}-$ induced displacement (Freda \& McDonald 1988, Gonzalez \& Dunson 1989). Further, some fish are able to take up ions at high rates when there is high diffusive ion leakage (Gonzalez et al. 1997, 1998), and at least two Amazon species have pHinsensitive $\mathrm{Na}^{+}$transporter (GonZalez \& WiLson 2001). For FredA $\&$ McDonald (1988), two important abilities may respond for the interspecific differences in acid tolerance: limitation of the ionic leakiness prompted by low $\mathrm{pH}$, and ion transporter recovery from the low $\mathrm{pH}$ inhibition.

Besides their own endogenous mechanisms, fish native to DOC-enriched habitats may relay on the great amount of organic substances found there to improve ion homeostasis (Gonzalez et al. 1998, 2002, Wood et al. 2002, 2003). Gonzalez et al. (2002) and Matsuo \& VAL (2007) observed that the presence of DOC in acidic water reduced both $\mathrm{Na}^{+}$influx inhibition and diffusive efflux stimulation in teleosts native to
Amazonia. The role of DOC to bind fish gills at low $\mathrm{pH}$ and promote physiological benefits (CAMPBELL et al. 1997) may be comparable with the above-mentioned action of elevated waterborne levels of $\mathrm{Ca}^{2+}$, that is, stabilization of tight junctions and prevention of ion losses. That would override any protective effect otherwise achieved by the divalent ion (Wood et al. 2003 , 2011). Besides, it could result from the ability of the organic molecules to bind to ion apical transporters and help concentrate $\mathrm{Na}^{+}$and $\mathrm{Cl}^{-}$ions by complexation, or to help deliver the ions to the uptake sites, which is normally credited to mucus (Gonzalez et al. 2002, SteInberg et al. 2007).

Except when $\mathrm{pH}$ was 4.2 , at which the presence of HA was associated with a slightly higher $\mathrm{Na}^{+}$plasma level in silver catfish, there were no differences in the ion levels between the different HA concentrations at any given $\mathrm{pH}$. This could be explained by the observation that this fish species is not native to waters with high DOC content, so its gill physiology may not be sensitive to the DOC's protective mechanism (MATsuo et al. 2004). Another possibility is that commercial $\mathrm{HA}$ is not as useful to silver catfish as natural black water, as observed by WooD et al. (2003) in stingrays (Potamotrygon sp.): $\mathrm{HA}$ stimulated $\mathrm{Na}^{+}$and $\mathrm{Cl}^{-}$leakage, probably because its high affinity for cations ends up stripping $\mathrm{Ca}^{2+}$ from the gills. Consequently, the authors concluded that this source of DOC may have different binding characteristics than does natural black water DOC.

The inhibitory mechanism of $\mathrm{Cl}^{-}$uptake under low $\mathrm{pH}$ is possibly associated with the already described mechanism of $\mathrm{Na}^{+}$uptake inhibition. Besides, it could be due to a reduction in intracellular $\mathrm{HCO}_{3}^{-}$at the chloride cells, thus exhausting the apical $\mathrm{Cl}^{-} / \mathrm{HCO}_{-3}$ exchanger (Wood 2001). $\mathrm{Cl}^{-}$loss in silver catfish was exacerbated at 25 and $50 \mathrm{mg} \mathrm{L}^{-1} \mathrm{HA}$ in the fish exposed to $\mathrm{pH} 4.0$, thus demonstrating a greater involvement of $\mathrm{HA}$ in $\mathrm{Cl}^{-}$than in $\mathrm{Na}^{+}$flux. Such difference may be linked to their distinct ionoregulatory mechanisms across the gill epithelium, since $\mathrm{Cl}^{-}$and $\mathrm{Na}^{+}$are exchanged for base and acid equivalents, respectively (Goss \& Wood 1990).

Comparing with the responses on $\mathrm{Na}^{+}$and $\mathrm{Cl}^{-}$balance, a different effect of HA was observed with regard to the dynamics of $\mathrm{K}^{+}$regulation. When there was no $\mathrm{HA}$ in the test water, the levels of $\mathrm{K}^{+}$in silver catfish exposed to $\mathrm{pH} 4.0$ and 4.2 were higher in comparison to ion levels in fish subjected to $\mathrm{pH}$ 7.0. A similar outcome was observed in the pirapitinga, Piaractus brachypomus, in a recent investigation (GARCIA et al. 2014). Further, Zaions \& BaLdisserotto (2000) found lower body levels of $\mathrm{K}^{+}$in silver catfish subjected to $\mathrm{pH} 7.0$ than in those subjected to either acidic or alkaline pH. MATHAN et al. (2010) also observed higher plasma $\mathrm{K}^{+}$levels in the common carp, Cyprinus carpio, after exposure to acidic $\mathrm{pH}$, and suggested that it could be due to a release of $\mathrm{K}^{+}$ from the muscle cells as $\mathrm{H}^{+}$enters them. Another study assessing plasma ion levels in silver catfish exposed to Aldrich HA ( 0 , 2.5 and $5 \mathrm{mg} \mathrm{L}^{-1}$ ) at $\mathrm{pH} \sim 7.0$ observed a progressive increase in $\mathrm{K}^{+}$levels with increased HA concentrations, suggesting that HA 
could limit gill permeability (Riffel et al. 2014). In this study HA did not influence $\mathrm{K}^{+}$levels at $\mathrm{pH}$ 7.0, while at the intermediate $\mathrm{pH}$ levels (4.0 and 4.2) its presence caused a marked decrease in ion levels. Thus, all concentrations of HA were able to counteract increased $\mathrm{K}^{+}$levels caused by $\mathrm{pH} 4.0$ and 4.2 , bringing $\mathrm{K}^{+}$ levels back to normal values for the species (Bolner \& BaLdisserotTo 2007), at pH 7.0.

Low $\mathrm{pH}$ exposure induced continuous net branchial losses of $\mathrm{Na}^{+}, \mathrm{Cl}^{-}$and $\mathrm{K}^{+}$, and a progressive decline in plasma $\mathrm{Na}^{+}$and $\mathrm{Cl}^{-}$levels in rainbow trout (McDonald \& Wood 1981). In spite of an improved tolerance to acidity reported for fish that are exposed to gradual water acidification in the wild, it is possible that the same fish will undergo ion loss when faced with sudden environmental acidification. For instance, ARIDE et al. (2007) found that plasma levels of $\mathrm{Na}^{+}$and $\mathrm{K}^{+}$in the tambaqui were reduced in acidic water compared to a circumneutral water. WILSON et al. (1999) observed that acid exposure produced different patterns of $\mathrm{Na}^{+}, \mathrm{Cl}^{-}$and $\mathrm{K}^{+}$fluxes in three Amazon fish, which implies that acid tolerance is not necessarily a typical feature of the fish that inhabit this region. Instead, it is largely related to the occurrence of these fish in the blackwater areas of that ecosystem, which are known to impose higher levels of acidity on the species.

Although HA showed some positive effects on hematological and plasma $\mathrm{K}^{+}$changes provoked in silver catfish by acidic $\mathrm{pH}$ exposure, the overall findings suggest that HA does not protect this species against acidic $\mathrm{pH}$ burden, since it increased mortality and $\mathrm{Cl}^{-}$loss at $\mathrm{pH}$ 4.0.

\section{ACKNOWLEDGMENTS}

The authors thank Conselho Nacional de Desenvolvimento Científico e Tecnológico (CNPq) for the research fellowship to B. Baldisserotto and Fundação de Amparo à Pesquisa do Estado do Rio Grande do Sul (FAPERGS) and Coordenação de Aperfeiçoamento de Pessoal de Nível Superior, Brazil (Capes) for the graduate fellowships to L.T. Gressler and F.J. Sutili respectively. This work was funded by CNPq and Fundação de Amparo à Pesquisa do Estado do Amazonas (FAPEAM - INCT ADAPTA).

\section{LITERATURE CITED}

Aride PHR, Roubach R, Val AL (2007) Tolerance response of tambaqui Colossoma macropomum (Cuvier) to water $\mathrm{pH}$. Aquaculture Research 38: 588-594. doi: 10.1111/j.13652109.2007.01693.x

Bindon SD, Gilmour KM, Fenwick JC, Perry SF (1994) The effects of branquial chloride cell proliferation on respiratory function in the rainbow trout Oncorhyncus mykiss. Journal of Experimental Biology 197: 47-63.

Bolner KCS, BaLdisserotto B (2007) Water pH and urinary excretion in silver catfish Rhamdia quelen. Journal of Fish Biology 70: 50-64. doi: 10.1111/j.1095-8649.2006.01253.x
Boyd CE, TUCKer CS (1992) Water quality and pond soil analyses for aquaculture. Auburn, Alabama Agricultural Experiment Station, Auburn University, 183p.

Brown BA (1976) Hematology: Principles and procedures. Philadelphia, Lea \& Febiger, 336p.

Campbell PGC, Twiss MR, Wilkinson KJ (1997) Accumulation of natural organic matter on the surfaces of living cells: implications for the interaction of toxic solutes with aquatic biota. Canadian Journal of Fisheries and Aquatic Sciences 54: 2543-2554.

Copatti CE, Codebella iJ, Radünz Neto J, Garcia lO, Rocha MC, BaLdisserotto B (2005) Effect of dietary calcium on growth and survival of silver catfish fingerlings, Rhamdia quelen (Heptapteridae), exposed to different water $\mathrm{pH}$. Aquaculture Nutrition 11: 345-350. doi: 10.1111/j.1365-2095.2005.00355.x Cunha MA, Zeppenfeld CC, Garcia LO, Loro VL, Fonseca MB, Emanuelli T, Veeck APD, Copatti CE, Baldisserotto B (2010) Anesthesia of silver catfish with eugenol: time of induction, cortisol response and sensory analysis of fillet. Ciência Rural 40: 2107-2114. doi: 10.1590/S0103-84782010005000154

Dheer JMS, Dheer TR, Mahajan CL (1987) Haematological and haematopoetic responses to acid stress in an air-breathing freshwater fish, Channa punctatus. Journal of Fish Biology 30: $577-588$

Dorafshan S, KalbAssi MR, Pourkazemi M, Amiri BM, Karimi SS (2008) Effects of triploidy on the Caspian salmon Salmo trutta caspius haematology. Fish Physiology and Biochemistry 34: 195200. doi: 10.1007/s10695-007-9176-Z

Duarte RM, Ferreira MS, Wood CM, Val AL (2013) Effect of low $\mathrm{pH}$ exposure on $\mathrm{Na}^{+}$regulation in two cichlid fish species of the amazon. Comparative Biochemistry and Physiology a-Molecular \& Integrative Physiology 166: 441-448. doi: 10.1016/j.cbpa.2013.07.022

Eaton AD, Clesceri LS, Rice EW, Grennierg AE (2005) Standard methods for the examination of water and wastewater. Springfield, American Public Health Association, 21st ed., 1600p.

Farjalla VF, Amado AM, Suhett AL, Meirelles-Pereira F (2009) DOC removal paradigms in highly humic aquatic ecosystems. Environmental Science and Pollution Research 16: 531538. doi: 10.1007/s11356-009-0165-x

Freda J, McDonald DG (1988) Physiological correlates of interspecific variation in acid tolerance in fish. The Journal of Experimental Biology 136: 243-258.

Garcia LO, Gutiérres-Espinosa MC, VÁsques-Torres W, Baldisserotto B (2014) Dietary protein levels in Piaractus brachypomus submitted to extremely acidic or alkaline $\mathrm{pH}$. Ciência Rural 44: 301-306. doi: 10.1590/S0103-84782014000200017

GonZalez RJ, Dunson WA (1989) Acclimation of sodium regulation to low $\mathrm{pH}$ and the role of calcium in the acidtolerant sunfish Enneacanthus obesus. Physiologycal Zoology 62: 977-992.

Gonzalez RJ, Wilson RW (2001) Patterns of ion regulation in acidophilic fish native to the ion-poor acidic Rio Negro. 
Journal of Fish Biology 58: 1680-1690. doi: 10.1111/j.10958649.2001.tb02322.x

Gonzalez RJ, Dalton VM, Patrick ML (1997) Ion regulation in ion-poor, acidic water by the blackskirt tetra (Gymnocorymbus ternetzi), a fish native to the Amazon River. Physiological Zoology 70: 428-435.

Gonzalez RJ, Wood CM, Wilson RW, Patrick ML, Bergman HL, Narahara A, VAL AL (1998) Effects of water pH and calcium concentration on ion balance in fish of the Rio Negro, Amazon. Physiological Zoology 71: 15-22.

Gonzalez RJ, Wilson RW, Wood CM, Patrick ML, Val AL (2002) Diverse strategies for ion regulation in fish collected from the ion-poor, acidic Rio Negro. Physiological and Biochemical Zoology 75: 37-47. doi: 10.1086/339216

Goss GG, Wood CM (1990) Kinetic analysis of the relationships between ion exchange and acid-base regulation at the gills of freshwater fish, p. 119-136. In: TRUсHот JP, LAHLOU B (Eds.). Animal Nutrition and Transport Processes. 2. Transport, Respiration and Excretion: Comparative and Environmental Aspects. Basel, Karger Publishers.

Greco AM, Fenwick JC, Perry SF (1996) The effects of soft-water acclimation on gill structure in the rainbow trout Oncorhynchus mykiss. Cell and Tissue Research 285: 75-82.

Holland A, Duivenvoorden LJ, Kinnear SHW (2014) The doubleedged sword of humic substances: contrasting their effect on respiratory stress in eastern rainbow fish exposed to low pH. Environmental Science and Pollution Research 21: 1701-1707. doi: 10.1007/s11356-013-2031-0

Küchler IL, Miekeley N, Forsberg BR (2000) A contribution to the chemical characterization of rivers in the rio Negro basin, Brazil. Journal of the Brazilian Chemical Society 11: 286292. doi: 10.1590/S0103-50532000000300015

Lima RL, Braun N, Kochhann D, Lazzari R, Radünz-Neto J, Moraes BS, LoRo V, BALDISSEROTTO B (2011) Survival, growth and metabolic parameters of silver catfish, Rhamdia quelen, juveniles exposed to different waterborne nitrite levels. Neotropical Ichthyology 9: 147-152. doi: 10.1590/S1679-62252011005000004

Lin H, DJ Randall (1993) Proton ATPase activity in crude homogenates of fish gill tissue: inhibitor sensitivity and environmental and hormonal regulation. Journal of Experimental Biology 180: 163-174.

Mathan R, Kurunthachalam SK, Priya M (2010) Alterations in plasma electrolyte levels of a freshwater fish Cyprinus carpio exposed to acidic pH. Toxicological and Environmental Chemistry 92: 149-157. doi: 10.1080/02772240902810419

Matsuo AYO, Val AL (2007) Acclimation to humic substances prevents whole body sodium loss and stimulates branchial calcium uptake capacity in cardinal tetras Paracheirodon axelrodi (Schultz) subjected to extremely low pH. Journal of Fish Biology 70: 989-1000. doi: 10.1111/j.10958649.2007.01358.x

Matsuo AYO, Playle RC, Val AL, Wood CM (2004) Physiological action of dissolved organic matter in rainbow trout in the presence and absence of copper: sodium uptake kinetics and unidirectional flux rates in hard and softwater. Aquatic Toxicology 70: 63-81. doi: 10.1016/j.aquatox.2004.07.005 McDonald D, Wood CM (1981) Branchial and renal acid and ion fluxes in the rainbow trout, Salmo gairdneri, at low environmental pH. Journal of Experimental Biology 93: 101-118.

McGeer JC, Szebedinszky C, McDonald DG, Wood CM (2002) The role of dissolved organic carbon in moderating the bioavailability and toxicity of $\mathrm{Cu}$ to rainbow trout during chronic waterborne exposure. Comparative Biochemistry and Physiology C 133: 147-160. doi: 10.1016/S15320456(02)00084-4

Milligan CL, Wood CM (1982) Disturbances in haematology, fluid volume distribution and circulatory function associated with low environmental $\mathrm{pH}$ in the rainbow trout, Salmo Gairdneri. Journal of Experimental Biology 99: 397415.

Miron DS, Becker AG, Loro VL, Baldisserotto B (2011) Waterborne ammonia and silver catfish, Rhamdia quelen: survival and growth. Ciência Rural 41: 349-353. doi: 10.1590/S0103-84782011000200028

Riffel APK, Saccol EMH, Finamor IA, Ourique GM, Gressler LT, Parodi T, Goulart LOR, Llesuy S, Baldisserotto B, Pavanato MA (2014) Humic acid and moderate hypoxia alter oxidative and physiological parameters in different tissues of silver catfish (Rhamdia quelen). Journal of Comparative Physiology B 184: 469-482. doi: 10.1007/s00360-014-0808-1

Sampaio FG, Boijink CL, Oba ET, Santos LRB, Kalinin AL, Rantin FT (2008) Antioxidant defenses and biochemical changes in pacu (Piaractus mesopotamicus) in response to single and combined copper and hypoxia exposure. Comparative Biochemistry and Physiology C 147: 43-51. doi: 10.1016/ j.cbpc.2012.07.002

Steinberg CeW, Saul N, Pietsch K, Meinelt T, Rienau S, Menzel R (2007) Dissolved humic substances facilitate fish life in extreme aquatic environments and have the potential to extend the lifespan of Caenorhabditis elegans. Annals of Environmental Science 1: 81-90.

Tavares-Dias M, Melo JFB, Moraes G, Moraes FR (2002) Características hematológicas de teleósteos brasileiros: VI. Variáveis do jundiá Rhamdia quelen (Pimelodidae). Ciência Rural 32: 693-698. doi: 10.1590/S0103-84782002000400024

Tavares-Dias M, Bozzo FR, Sandrin EFS, Campos-Filho E, Moares FR (2004) Células sanguíneas, eletrólitos séricos, relação hepato e esplenossomática de carpa comum, Cyprinus carpio (Cyprinidae) na primeira maturação gonadal. Acta Scientiarum Biological Sciences 26: 73-80. doi: 10.4025/ actascibiolsci.v26i1.1661

Thurman EM (1985) Organic geochemistry of natural waters. Dordrecht, Martinus Nijhof, Dr. W. Junk Publishers, 507p. Verdouw H, Van Echteld CJA, Dekkers EMJ (1978) Ammonia determination based on indophenols formation with 
sodium salicylate. Water Research 12: 399-402. doi: 10.1016/0043-1354(78)90107-0

Wendelaar Bonga SE (1997) The stress response in fish. Physiology Reviews 77: 591-625.

Wilson RW, Wood CM, Gonzalez RJ, Patrick ML, Bergman HL, Narahara A, VAL AL (1999) Ion acid-base balance in three species of Amazonian fish during gradual acidication of extremely soft water. Physiological and Biochemical Zoology 72: 277-285.

Wood CM, McDonald DG (1982) Physiological mechanisms of acid toxicity to fish, p. 197-226. In: JoHnson RE (Ed.). Acid Rain/Fisheries: Proceedings of an International Symposium on Acid Precipitation and Fishery Impacts in NorthEastern North America. Ithaca, American Fisheries Society. Wood CM, Wilson RW, Gonzalez RJ, Patrick ML, Bergaman HL, Narahara A, Val AL (1998) Responses of an Amazonian teleost, the tambaqui (Colossoma macropomum) to low $\mathrm{pH}$ in extremely soft water. Physiologycal and Biochemical Zoology 71: 658-670.

Wood CM (2001) Toxic response of the gill, p. 1-89. In: SCHLENK D, BENSON WH (Eds.). Target organ toxicity in marine and freshwater teleosts. London, Taylor \& Francis.

Wood CM, Matsuo AYO, Gonzalez RJ, Wilson RW, Patrick ML, VAL AL (2002) Mechanisms of ion transport in Potamotrygon, a stenohaline freshwater elasmobranch native to the ionpoor blackwaters of the Rio Negro. Journal of Experimental Biology 205: 3039-3054.

Wood CM, Matsuo AYO, Wilson RW, Gonzalez RJ, Patrick ML, Playle RC, VAL AL (2003) Protection by natural blackwater against disturbances in ion fluxes caused by low $\mathrm{pH}$ exposure in freshwater stingrays endemic to the Rio Negro. Physiological and Biochemical Zoology 76: 12-27. doi: 10.1086/367946

Wood CM, Al-Reasi HA, Scott DS (2011) The two faces of DOC. Aquatic Toxicology 105S: 3-8. doi: 10.1016/j.aquatox.2011. 03.007

Zaions MI, BaLdisserotto B (2000) $\mathrm{Na}^{+}$and $\mathrm{K}^{+}$body levels and survival of fingerlings of Rhamdia quelen (Siluriformes, Pimelodidae) exposed to acute changes of water pH. Ciência Rural 30: 1041-1045. doi: 10.1590/S0103-84782000000600020

Zall DM, Fisher M, Garner MQ (1956) Photometric determination of chlorides in water. Analytical Chemistry 28: 1665-1678. doi: 10.1021/ac60119a009

Submitted: 13 November 2014

Received in revised form: 3 April 2015

Accepted: 22 April 2015

Editorial responsibility: Carolina Arruda Freire 